\title{
Volker Oesterreich
}

\section{O pewnym zabójstwie}

\section{na tle politycznym i jego wielorakich skutkach ${ }^{1}$}

Do akcji przygotowywał się długo i starannie, napędzany ślepą nienawiścią, fanatyzmem politycznym i religijnym obłędem. Jakaż to niezwykle wybuchowa mieszanka. 23-letni student teologii z Jeny, Carl Ludwig Sand, ruszył pieszo do Mannheim, by 23 marca 1819 roku zamordować odnoszącego ogromne sukcesy pisarza Augusta von Kotzebuego w jego położonym $\mathrm{w}$ kwadracie $\mathrm{A} 2^{2}$ mieszkaniu. „Z brutalnością ciął swoją ofiarę najpierw w twarz, na co pisarz odruchowo podniósł ręce do góry, odsłaniając tym samym tułów na dalsze ciosy sztyletu". Taką relację przekazuje Otto von Kotzebue, mieszkający w Monachium praprawnuk ofiary, a jego opowieść brzmi tak drastycznie, jakby sam był świadkiem zamachu: „Krew Augusta von Kotzebuego popłynęła do pomieszczenia, w którym bawił się jego mały synek, a mój pradziadek. Z innego pokoju

1 Tekst jest skróconym tłumaczeniem następującego artykułu Volkera OesTERREICHA: Ausstellung zum Attentat von Carl Ludwig Sand auf August von Kotzebue vor 200 Jahren. Ein politischer Mord mit vielen Folgen - Titel „Lohn der Wahrheit? https://www. rnz.de/panorama/magazin_artikel,-universitaetsbibliothek-mannheim-ausstellung-zum-a ttentat-von-carl-ludwig-sand-auf-august-von-kotzebu-_arid,428684.html (22.06.2020). Dziękuję Volkerowi Oesterreichowi za zgodę na publikację tłumaczenia - N.N.M.

${ }^{2}$ W XVII wieku centrum miasta Mannheim zostało zaprojektowane na planie szachownicy. Do dzisiaj mieszkańcy podają nazwy kwadratów, a nie ulic, przy których mieszkają. Przyp. tłum. 
nadbiegła ciężarna matka chłopca, niosąc na rękach najmłodsze dziecko. Wkrótce potem poroniła; to skutek tego przestępstwa"3.

83-letni Otto jest oburzony faktem, „że do dzisiaj szerzy się szaleńczy kult tego mordercy". Jego zdaniem Sand był ledwie płotką, a nie żadnym bojownikiem o wolność. „A już na pewno nie męczennikiem, na jakiego ustylizowali go członkowie burszenszaftów i jego potomkowie. Morderca był „napompowany narodowym nadęciem i patosem”, a jego kult winien się wreszcie skończyć.

W opublikowanych w 1821 roku wycinkach akt z procesu (ActenAuszüge aus dem Untersuchungs-Proceß über Carl Ludwig Sand) można przeczytać, że dopuściwszy się zbrodni, student wykrzyknął: „Dzięki Bogu, dokonało się”, a następnie: „Niech żyje moja niemiecka ojczyzna". Potem próbował odebrać sobie życie, lecz tylko poranił się sztyletem. Został aresztowany, a heidelberski lekarz Maximilian Joseph Chelius, właściciel położonego przy głównej ulicy pałacu Palais Morass (dzisiaj znajduje się w nim Kurpfälzisches Museum), wraz z innymi lekarzami zaopatrzył jego silnie ropiejące rany. Student mógł wziąć udział $\mathrm{w}$ procesie, który zakończył się wyrokiem śmierci, podpisanym przez wielkiego księcia Badenii ${ }^{4}$.

Wyrok wykonano 20 maja 1820 roku - 24-latek został ścięty na szafocie. Z drewna użytego do budowy szafotu kat zbudował sobie domek w położonym w Heidelbergu ogródku warzywnym. Ledwo budowa się skończyła, na miejsce zaczęli pielgrzymować zwolennicy Sanda, aby wyciąć sobie parę relikwii. „Domek kata” stoi do dzisiaj przy ulicy Steigerweg $55 \mathrm{~A}$ w Heidelbergu; wciąż jeszcze ma w nim tkwić kilka belek z szafotu.

Lecz co tak naprawdę popchnęło Sanda do tego straszliwego czynu? Podczas demonstracji studenckich (Wartburgfest) w 1817 roku pochodzący z Wundsiedel student widział, jak spalono dzieło Kotzebuego Geschichte des deutschen Reichs (1814/15). Mówiło się o tym, że ten niezwykle popularny autor i rosyjski radca stanu ma być szpiegiem carskiego dworu, że nie jest „niemieckiej krwi”. Rozpowiadano też, że jest przeciwnikiem studentów zrzeszonych $\mathrm{w}$ burszenszaftach i uwodzicielem młodych ludzi. „To wszystko bzdura”, twierdzi jego praprawnuk, zapytany w wywiadzie. Zaś w zamachu sprzed 200 lat dostrzega wzorcowy przykład na to, do czego mogą doprowadzić propaganda, fanatyzm i ślepa nienawiść.

${ }^{3}$ Wszystkie wypowiedzi Otto von Kotzebuego pochodzą z listu skierowanego do autora tekstu w styczniu 2019 roku oraz z wywiadu przeprowadzonego z nim w marcu 2019 roku.

${ }^{4}$ Cramer Friedrich (Hg. 1821): Acten-Auszügen aus dem Untersuchungs-Proceß über Carl Ludwig Sand. Altenburg, Leipzig: Verlag des literarischen Comptoirs. 
Jednym z siewców nienawiści był w owym czasie Ernst Moritz Arndt. Ów pisarz i historyk mianował nienawiść na religię Niemców. Całkiem podobnie zresztą jak Friedrich Ludwig Jahn, ojciec gimnastyki sportowej, który ogłosił, że nienawiść do wszystkiego, co obce, jest obowiązkiem każdego Niemca. „Dzisiaj wiele rzeczy pogarsza jeszcze Internet", twierdzi Otto von Kotzebue. Nim ruszą do czynu, zamachowcy ciągle odwołują się do religijnych lub ideologicznych instancji. Carl Ludwig Sand i światowy terroryzm - to dwie strony tego samego medalu.

Zaślepiony student był w swoich oczach bojownikiem o wolność, walczącym o postępowe, zjednoczone Niemcy. O państwo pozbawione samowoli książąt. Udało mu się jednak osiągnąc coś dokładnie przeciwnego. Z chwilą wprowadzenia w życie postanowień karlsbadzkich z 1819 roku nastały mroczne czasy. Tendencje narodowe i liberalne zaczęto zwalczać za pomoca metod państwa policyjnego. Szpiclowanie i cenzura były na porządku dziennym, uniwersytety znalazły się pod nadzorem [państwa], odbierano prawo do wykonywania zawodu. Rzeczy miały się coraz to gorzej, aż w końcu, po rewolucji lipcowej z 1830 roku, wolne duchy, takie jak Heinrich Heine i Ludwig Börne, wyemigrowały do Paryża. Stamtąd docierał do nich powiew świeżego powietrza.

Wszystkie te aspekty zostały poruszone podczas małej, lecz zgrabnie urządzonej wystawy, którą w 2019 roku zorganizowano w bibliotece uniwersyteckiej w Mannheim, oddalonej ledwie rzut kamieniem od historycznego miejsca zbrodni. Pokazano na niej liczne dokumenty związane z pisarzem, przede wszystkim zaś jego książki, ale także narzędzie zbrodni, sztychy ukazujące miejsce zamachu oraz historyczne doniesienia prasowe na temat postanowień karlsbadzkich. Na zaprezentowanej publiczności masce pośmiertnej Kotzebuego można było zobaczyć ślad po ranie kłutej na jego twarzy. Wystawie towarzyszyło kilkudniowe sympozjum, którego pokłosiem ma być zaplanowana na 2020 rok publikacja.

Wystawa uzmysłowiła również, jak bardzo sceny teatralne biły się o sztuki Kotzebuego. Urodzony w 1761 roku dramatopisarz, na którego podejrzliwym okiem łypał Goethe, był na początku XIX wieku maszynką do robienia pieniędzy par excellence. „Nienawidzili go, lecz go potrzebowali", mówi Otto von Kotzebue o relacjach między prapradziadem a weimarskimi klasykami. I jeśli spojrzeć na fakty, to ma rację: podczas 26 lat, gdy dyrektorem weimarskiego teatru był Goethe, wystawiono 601 sztuk, z czego 87 autorstwa Kotzebuego; swoje własne dramaty Goethe wprowadzał do repertuaru o wiele rzadziej ${ }^{5}$. Jeszcze

${ }^{5}$ Por. Nedden Otto C.A. (1985): Nachwort. In: August von Kotzebue: Die deutschen Kleinstädter. Stuttgart: Reclam: $87 \mathrm{f}$. 
i większe wrażenie robia liczby w przypadku teatru narodowego w Mann-

$\rightarrow$ heim: tam w latach 1782-1839 wystawiano Schillera ledwie 276 razy, podczas gdy Kotzebuego aż $1487^{6}$. Pisarz był twórcą scenicznych bestsellerów, także w sensie międzynarodowym. Dzisiaj jednak nie pamięta o nim właściwie nikt. A napisał przecież aż 230 sztuk teatralnych, zaś jego dzieła zebrane są pomieszczone w 40 tomach.

„Pewnie, że wiele tych utworów jest bardzo słabych”, mówi potomek Kotzebuego. Ale z drugiej strony pisarz był bardzo postępowy. Opowiadał się za równouprawnieniem kobiet i „tolerancją religijną, zaś jego dramat Die Negersklaven (1796) to gorący apel o zniesienie niewolnictwa". Do dzisiaj najsłynniejszym utworem Kotzebuego jest komedia Miasteczko niemieckie. Komedya we 4-ech aktach (Die deutschen Kleinstädter), odczytana z okazji dwusetnej śmierci pisarza na deskach sceny studyjnej teatru narodowego w Mannheim wiosną 2019 roku. Wystawiona po raz pierwszy w 1802 roku sztuka opowiada o kołtunach z miasteczka Krähwinkel (Zaściankowo), w którym poważaniem cieszą się tylko ci, którzy noszą imponujący tytuł. Przez zacofanie jego mieszkańców nieomal rozpada się rodząca się dopiero co miłość między córką burmistrza Sabiną i jej ukochanym. Wiele dialogów jest napisanych jako żywo na scenę: tym bardziej zadziwia fakt, że ignorują go producenci teatralni. Współcześni pisarzowi bardzo dobrze wiedzieli, że stosunki panujące w Krähwinkel były aluzyjną ilustracją ówczesnego Weimaru. Po ponad 200 latach od jego śmierci nadszedł wreszcie czas, aby skierować światło ramp na przynajmniej jedno z jego dzieł.

${ }^{6}$ Zgodnie z ustną informacją otrzymaną od Liselotte Homering, kierowniczką działu zbiorów teatralnych muzeów Reiss-Engelhorn-Museen w Mannheim.

7 Tłumaczył Stanisław hrab. Broel-Plater (1872). Rękopis tłumaczenia dostępny na serwerze Wielkopolskiej Biblioteki Cyfrowej. Tytuł dramatu właściwie powinien brzmieć: Małomieszczańscy Niemcy. Przyp. tłum.

Nina Nowara-Matusik

(D) http://orcid.org/0000-0002-7088-0395

Uniwersytet Śląski w Katowicach 